\title{
A clinico-pathological and follow up study of 10 cases of essential type II cryoglobulinaemic neuropathy
}

\author{
Guido Cavaletti, Maria Grazia Petruccioli, Vittorio Crespi, Pietro Pioltelli, \\ Paola Marmiroli, Giovanni Tredici
}

\begin{abstract}
Ten patients with essential cryoglobulinaemia type II were examined for peripheral nerve damage. In six cases distal symmetrical nerve involvement was present, while in three other cases abnormalities restricted to single nerves were found. Electrophysiological and morphological data were consistent with axonal damage, the larger myelinated fibres being most affected. Although active signs of vasculitis and immunoperoxidase staining for immunoglobulins were not present, endoneurial vessels were widely damaged, with abnormally thick endothelial cells and redundant basal membranes. These findings, together with a patchy distribution of myelinated fibre loss, suggest ischaemia as a cause of peripheral neuropathy during essential cryoglobulinaemia type II. A follow up examination, performed one year after haematologial remission, revealed that no further peripheral nerve damage had occurred.
\end{abstract}

The incidence of peripheral neuropathy during cryoglobulinaemias has been reported to vary from $7 \%$ to $60 \% .^{1-3}$ The pathogenesis of peripheral nerve damage is still not completely understood and different mechanisms have been suggested. ${ }^{45}$ There is a paucity of studies of large series of patients, homogeneous as regards haematological disorders and cryoglobulin type, in which the peripheral nervous system has been studied clinically, electrophysiologically and morphologically. This may explain the heterogeneity of pathological features previously reported. We studied the peripheral nerves in a series of 10 patients affected by essential cryoglobulinaemia type II (ECII). The subjects were evaluated clinically, electrophysiologically and morphologically to assess the occurrence and features of peripheral nervous system involvement at baseline and one year after the first examination.

\section{Materials and methods}

All the patients with definite ECII under observation on 1 October 1987 by the haematological department were included in this study. They were screened for inflam- matory, dysmetabolic, nutritional, toxic, paraneoplastic or inherited causes of peripheral neuropathy before entering the study. The table reports the clinical data. The degree of peripheral nerve damage was quantitatively assessed by means of the Neurological Symptom Score (NSS, normal values 0-1) and of the Neurological Disability Score (NDS, normal values $<6$ ) described by Dyck et al. ${ }^{6}$ Ulnar, median, peroneal and sural nerves were electrophysiologically tested with surface electrodes and concentric needle electromyography was performed in distal muscles of the arms and legs. Skin temperature was controlled and kept over $34^{\circ} \mathrm{C}$ with a thermostated infra-red lamp. Reference was made to our laboratory normal values, (mean, 2.5 SD), obtained in 60 healthy subjects.

An electrophysiological diagnosis of polyneuropathy was made when abnormal values were found at least for two parameters in two different nerves or in one nerve and one muscle not dependent on the same nerve. Complete sural nerve biopsies at the ankle were obtained in six patients (with their informed consent) and were processed for light and electron microscopy with standard methods. Data from sural nerve biopsies obtained within two hours after death from eight healthy people (five males, three females, age $45-67$, mean $=58 \cdot 0$ ) who died because of traumatic brain injuries were used as a control. Morphometric evaluations were performed with an automatic image analyser (TAS Plus, Leitz $\mathrm{GmbH}$ ) and a statistical evaluation of endoneural components was obtained by superimposing a calibrated grid on micrographs at a final enlargement of $18000 \times$. Indirect immunoperoxidase staining was performed on paraffin-embedded sections using anti-human IgG and anti-human IgM antibodies. One year after the first neurological examination a follow up clinical and electrophysiological examination was performed. The course of ECII was evaluated with the haematological score proposed by the WHO, ${ }^{7}$ and with the ESR and complement fraction C4 values, while the general performances of the patients were scored with the Karnofsky scale. $^{8}$

\section{Results}

The presence of clinically evident polyneuropathy was suspected in six cases, with sensory involvement in five (cases $2,3,6,7$ 
Clinical, neurophysiological and bioptical data of all patients affected by EMCII

\begin{tabular}{|c|c|c|c|c|c|c|c|c|c|c|c|c|c|c|c|c|c|c|c|c|}
\hline Patient & 1 & & 2 & & 3 & & 4 & & 5 & & 6 & & 7 & & 8 & & 9 & & 10 & \\
\hline $\begin{array}{l}\text { Age/sex } \\
\text { Period of EMC }{ }^{\star \star} \\
\text { Cryocrit }(\dagger) \\
\text { Systemic }\end{array}$ & $\begin{array}{l}52 / \mathrm{m} \\
61 \\
2 \%\end{array}$ & & $\begin{array}{l}64 / \mathrm{f} \\
40 \\
1 \%\end{array}$ & & $\begin{array}{l}58 / \mathbf{f} \\
32 \\
\mathbf{3} \%\end{array}$ & & $\begin{array}{l}57 / \mathrm{f} \\
25 \\
1 \%\end{array}$ & & $\begin{array}{l}55 / \mathrm{m} \\
20 \\
1 \%\end{array}$ & & $\begin{array}{l}69 / \mathrm{f} \\
16 \\
2 \%\end{array}$ & & $\begin{array}{l}85 / \mathrm{m} \\
8 \\
2 \%\end{array}$ & & $\begin{array}{l}48 / \mathrm{f} \\
5 \\
3 \%\end{array}$ & & $\begin{array}{l}78 / \mathrm{f} \\
4 \\
23 \%\end{array}$ & & $\begin{array}{l}66 / \mathrm{f} \\
2 \\
5 \%\end{array}$ & \\
\hline $\begin{array}{l}\text { involvement }(\$) \\
\text { Total therapy }(\S)\end{array}$ & C & & C & & $\mathbf{C} / \mathbf{R}$ & & C & & - & & C & & C & & C & & C & & C & \\
\hline $\begin{array}{l}\text { CTX } \\
\text { PD } \\
\text { Neurological }\end{array}$ & $\begin{array}{r}3650 \\
320\end{array}$ & & $\begin{array}{r}14000 \\
700\end{array}$ & & $\begin{array}{l}6000 \\
1000\end{array}$ & & $\begin{array}{l}6800 \\
7800\end{array}$ & & $\begin{array}{l}\text { nt } \\
\text { nt }\end{array}$ & & $\begin{array}{l}8300 \\
\text { nt }\end{array}$ & & $\begin{array}{l}\text { nt } \\
\text { nt }\end{array}$ & & $\begin{array}{l}\text { nt } \\
\text { nt }\end{array}$ & & $\begin{array}{l}\text { nt } \\
\text { nt }\end{array}$ & & $\begin{array}{l}\text { nt } \\
\text { nt }\end{array}$ & \\
\hline $\begin{array}{l}\text { assessment } \\
\text { NSS } \\
\text { NDS } \\
\text { Median nerve }\end{array}$ & $\begin{array}{l}\mathrm{a} \\
2 \\
2\end{array}$ & $\begin{array}{l}\mathrm{b} \\
2 \\
3\end{array}$ & $\begin{array}{l}\mathrm{a} \\
2 \\
12\end{array}$ & $\begin{array}{l}\mathrm{b} \\
2 \\
12\end{array}$ & $\begin{array}{l}a \\
1 \\
7\end{array}$ & $\begin{array}{l}\mathrm{b} \\
1 \\
6\end{array}$ & $\begin{array}{l}\mathrm{a} \\
0 \\
0\end{array}$ & $\begin{array}{l}\mathbf{b} \\
0 \\
0\end{array}$ & $\begin{array}{l}a \\
3 \\
9\end{array}$ & $\begin{array}{l}b \\
1 \\
7\end{array}$ & $\begin{array}{l}a \\
2 \\
16\end{array}$ & $\begin{array}{l}b \\
1 \\
16\end{array}$ & $\begin{array}{l}a_{1} \\
13\end{array}$ & $\begin{array}{l}b \\
1 \\
12\end{array}$ & $\begin{array}{l}\mathbf{a} \\
0 \\
0\end{array}$ & b & $\begin{array}{l}a \\
1 \\
8\end{array}$ & b & $\begin{array}{l}\mathrm{a}_{0} \\
4\end{array}$ & $\begin{array}{l}\mathrm{b} \\
0 \\
3\end{array}$ \\
\hline $\begin{array}{l}\text { Median nerve } \\
\text { MCV } \\
\text { DL } \\
\text { MAP } \\
\text { SCV } \\
\text { SAP } \\
\text { F-wave } \\
\text { Ulnar nerve }\end{array}$ & $\begin{array}{l}57 \\
3 \cdot 8 \\
11 \\
53 \\
4 \cdot 8 \\
27 \cdot 4\end{array}$ & $\begin{array}{c}51 \\
3.9 \\
16 \\
51 \\
7 \\
26.6\end{array}$ & $\begin{array}{l}50 \cdot 5 \\
3 \cdot 3 \\
10 \\
61 \\
4 \cdot 5 \star \\
26\end{array}$ & $\begin{array}{l}53 \\
3 \cdot 3 \\
10 \\
55 \\
5 \\
24\end{array}$ & $\begin{array}{c}47^{\star} \\
4 \cdot 1 \\
12 \cdot 5 \\
35^{\star} \\
2^{\star} \\
29\end{array}$ & $\begin{array}{c}50 \\
4 \cdot 2 \\
7 \\
33^{\star} \\
2^{\star} \\
28\end{array}$ & $\begin{array}{l}54 \\
3.8 \\
14 \\
46 \\
7 \\
23\end{array}$ & $\begin{array}{c}53 \\
4 \cdot 2 \\
10 \\
46 \\
8 \\
24 \cdot 4\end{array}$ & $\begin{array}{l}55 \\
3 \cdot 8 \\
15 \\
44^{\star} \\
5 \\
27\end{array}$ & $\begin{array}{l}54 \\
3 \cdot 8 \\
18 \\
55 \\
5 \cdot 5 \\
26 \cdot 8\end{array}$ & $\begin{array}{l}51 \\
2 \cdot 6 \\
10 \\
56 \\
7.5 \\
25\end{array}$ & $\begin{array}{c}52 \\
2 \cdot 8 \\
8 \\
55 \\
4^{\star} \\
27\end{array}$ & $\begin{array}{c}54 \\
4 \cdot 2 \\
9 \\
42^{\star} \\
3^{\star} \\
29 \cdot 1\end{array}$ & $\begin{array}{c}51 \\
3 \cdot 9 \\
5 \cdot 5 \\
43^{\star} \\
4^{\star} \\
29\end{array}$ & $\begin{array}{l}54 \\
3 \\
14 \cdot 5 \\
53 \\
7 \\
25 \cdot 2\end{array}$ & $\begin{array}{l}\bar{z} \\
\bar{z} \\
\bar{z}\end{array}$ & $\begin{array}{c}54 \\
3.8 \\
9.5 \\
50 \\
7.5 \\
25.2\end{array}$ & $\begin{array}{l}\bar{z} \\
\bar{z}\end{array}$ & $\begin{array}{c}55 \\
3 \cdot 4 \\
6 \\
48 \\
4^{\star} \\
24 \cdot 6\end{array}$ & $\begin{array}{c}57 \\
3 \cdot 4 \\
7 \\
49 \\
3 \cdot 5^{\star} \\
24 \cdot 6\end{array}$ \\
\hline $\begin{array}{l}\text { MCV } \\
\text { DL } \\
\text { MAP } \\
\text { SCV } \\
\text { SAP } \\
\text { F-wave } \\
\text { Peroneal nerv }\end{array}$ & $\begin{array}{l}60 \\
2 \cdot 8 \\
17 \\
54 \\
3 \cdot 5 \\
27\end{array}$ & $\begin{array}{c}57 \\
3 \\
15 \\
46 \\
5 \cdot 5 \\
28 \cdot 4\end{array}$ & $\begin{array}{c}55 \cdot 5 \\
2 \cdot 9 \\
6 \\
\mathrm{nd}^{\star} \\
\mathrm{nd}^{\star} \\
26\end{array}$ & $\begin{array}{c}54 \\
3 \cdot 1 \\
6 \\
\text { nd }^{\star} \\
\text { nd } \\
26 \cdot 5\end{array}$ & $\begin{array}{c}60 \\
2 \cdot 8 \\
11 \\
36^{\star} \\
2^{\star} \\
25 \cdot 4\end{array}$ & $\begin{array}{l}58 \\
2 \cdot 3 \\
8 \\
34^{\star} \\
5 \\
25\end{array}$ & $\begin{array}{l}63 \\
2 \cdot 4 \\
14 \\
60 \\
4 \cdot 5 \\
22 \cdot 4\end{array}$ & $\begin{array}{l}57 \\
2 \\
14 \\
57 \\
12 \\
22 \cdot 8\end{array}$ & $\begin{array}{l}59 \\
3.2 \\
13.5 \\
42^{\star} \\
3.5^{\star} \\
26\end{array}$ & $\begin{array}{r}53 \\
3 \\
19 \\
50 \\
\times \quad 5 \\
26.6\end{array}$ & $\begin{array}{c}62 \\
2 \cdot 6 \\
6 \\
54 \\
4 \cdot 5 \\
24 \cdot 8\end{array}$ & $\begin{array}{c}55 \\
2 \cdot 3 \\
9 \\
54 \\
3 \cdot 5 \star \\
26 \cdot 8\end{array}$ & $\begin{array}{c}46^{\star} \\
3 \\
6 \\
37^{\star} \\
2^{\star} \\
28\end{array}$ & $\begin{array}{l}43^{\star} \\
3 \cdot 4^{\star} \\
83^{\star} \\
44^{\star} \\
29^{\star}\end{array}$ & $\begin{array}{l}61 \\
2 \cdot 5 \\
12 \\
61 \\
10 \\
26 \cdot 4\end{array}$ & $\begin{array}{l}= \\
\bar{z} \\
=\end{array}$ & $\begin{array}{l}59 \\
2.6 \\
12.5 \\
54 \\
6 \\
26.8\end{array}$ & $\begin{array}{l}= \\
\bar{z} \\
\end{array}$ & $\begin{array}{c}56 \\
2 \\
8 \\
52 \\
6 \\
24 \cdot 2\end{array}$ & $\begin{array}{c}56 \\
2 \cdot 3 \\
6 \\
51 \\
5 \cdot 5 \\
24 \cdot 2\end{array}$ \\
\hline $\begin{array}{l}\text { Peroneal nerve } \\
\text { MCV } \\
\text { DL } \\
\text { MAP } \\
\text { Sural nerve }\end{array}$ & $\begin{array}{r}46 \\
4 \\
8\end{array}$ & $\begin{array}{l}43^{\star} \\
3 \cdot 1 \\
7\end{array}$ & $\begin{array}{c}50 \\
3.8 \\
3.5\end{array}$ & $\begin{array}{r}43^{\star} \\
3 \cdot 1 \\
2 \cdot 5\end{array}$ & $\begin{array}{l}49 \\
4 \cdot 1 \\
2 \cdot 8\end{array}$ & $\begin{array}{l}46 \\
3 \cdot 4 \\
5\end{array}$ & $\begin{array}{r}50 \\
2.9 \\
7.5\end{array}$ & $\begin{array}{l}51 \\
2 \cdot 8 \\
5\end{array}$ & $\begin{array}{c}37 \star \\
3.9 \\
3\end{array}$ & $\begin{array}{r}41^{\star} \\
3.8 \\
3.7\end{array}$ & $\begin{array}{c}38^{\star} \\
3 \cdot 5 \\
1 \cdot 4^{\star}\end{array}$ & $\begin{array}{l}49 \\
5^{\star} \\
0.6^{\star}\end{array}$ & $\begin{array}{r}40 \star \\
4.4 \\
5.5\end{array}$ & $\begin{array}{l}40^{\star} \\
4 \cdot 6 \\
3\end{array}$ & $\begin{array}{c}47 \cdot 5 \\
3 \cdot 4 \\
5\end{array}$ & $=$ & $\begin{array}{r}42^{\star} \\
3 \cdot 4 \\
4 \cdot 5\end{array}$ & $\bar{z}$ & $\begin{array}{r}54 \\
3 \\
9\end{array}$ & $\begin{array}{l}56 \\
3 \cdot 6 \\
4\end{array}$ \\
\hline $\begin{array}{l}\text { SCV } \\
\text { SAP } \\
\text { EMG }\end{array}$ & $\begin{array}{r}45 \\
7\end{array}$ & $\begin{array}{r}44 \\
9\end{array}$ & $\begin{array}{l}\mathrm{nd}^{\star} \\
\mathrm{nd}^{\star}\end{array}$ & $\begin{array}{l}\mathrm{nd}^{\star} \\
\mathrm{nd}^{\star}\end{array}$ & $\begin{array}{r}46 \\
9\end{array}$ & $\begin{array}{r}50 \\
5\end{array}$ & $\begin{array}{l}50 \\
20\end{array}$ & $\begin{array}{l}55 \\
11\end{array}$ & $\begin{array}{l}50 \\
27\end{array}$ & $\begin{array}{l}52 \\
20\end{array}$ & $\begin{array}{l}\mathrm{nd}^{\star} \\
\mathbf{n d}^{\star}\end{array}$ & $\begin{array}{l}\mathrm{nd}^{\star} \\
\mathbf{n d}^{\star}\end{array}$ & $\begin{array}{r}46 \\
7\end{array}$ & $\begin{array}{r}47 \\
9\end{array}$ & $\begin{array}{r}53 \\
7\end{array}$ & $\overline{-}$ & $\begin{array}{l}52 \\
12\end{array}$ & $\overline{-}$ & $\begin{array}{r}48 \\
5\end{array}$ & $\begin{array}{r}52 \\
9\end{array}$ \\
\hline $\begin{array}{l}\text { opp poll } \\
\text { abd dig min } \\
\text { tib ant } \\
\text { Density of myelinated } \\
\text { fibres }\left({ }^{\wedge}\right) \\
\text { Teased fibres }(\mathcal{(})\end{array}$ & $\begin{array}{l}- \\
- \\
- \\
7680\end{array}$ & $\begin{array}{l}\mathbf{N}+ \\
\mathbf{N}+ \\
-\end{array}$ & $\begin{array}{l}\mathbf{N}++ \\
\mathbf{N}++ \\
\mathbf{N}+ \\
4680^{\circ}\end{array}$ & $\begin{array}{l}\mathbf{N}+ \\
\mathbf{N}++ \\
\mathbf{N}+\end{array}$ & $\begin{array}{l}\mathrm{N}+ \\
\bar{N}++ \\
9450\end{array}$ & $\begin{array}{l}\mathbf{N}++ \\
\mathbf{N}+ \\
\mathbf{N}++\end{array}$ & $\begin{array}{l}- \\
-\end{array}$ & $\begin{array}{l}- \\
-\end{array}$ & $\begin{array}{l}\dot{\bar{N}}+ \\
\mathbf{N}+\end{array}$ & $\begin{array}{l}\overline{\mathbf{N}}+ \\
\mathbf{N}+\end{array}$ & $\begin{array}{l}\overline{\mathbf{N}}+ \\
\mathbf{N}++ \\
2180^{\circ}\end{array}$ & $\begin{array}{l}\overline{\mathbf{N}+} \\
\mathbf{N}+\end{array}$ & $\begin{array}{l}\overline{\mathbf{N}}+ \\
\mathbf{N}+\end{array}$ & $\begin{array}{l}\mathbf{N}+ \\
\overline{\mathbf{N}}+\end{array}$ & $\bar{z}$ & & $\overline{\bar{N}}+$ & & $\bar{z}$ & $\bar{z}$ \\
\hline $\begin{array}{l}\text { A, B } \\
\text { C, D, F, G } \\
\text { E, H }\end{array}$ & $\begin{array}{l}86 \% \\
10 \% \\
4 \%\end{array}$ & & $\begin{array}{l}78 \% \\
8 \% \% \\
14 \%\end{array}$ & & $\begin{array}{l}72 \% \\
16 \% \\
12 \%\end{array}$ & & $\begin{array}{l}82 \% \\
15 \% \\
3 \%\end{array}$ & & $\begin{array}{l}80 \% \\
13 \% \\
7 \%\end{array}$ & & $\begin{array}{l}77 \% \\
15 \% \\
8 \%\end{array}$ & & & & & & & & & \\
\hline
\end{tabular}

$(\star \star)=$ Months from the first hematological definite diagnosis to the first neurological examination.

$(\dagger)=$ At the first hematological examination; $(\ddagger) \quad \mathbf{C}=$ cutaneous involvement, $\mathbf{R}=$ renal involvement; (\$) CTX $=$ cyclophosphamide (mg/m ${ }^{2}$, $\mathrm{PD}=$ prednisone $\left(\mathrm{mg} / \mathrm{m}^{2}\right), \mathrm{nt}=$ not treated

$a=$ Baseline examination; $b=$ one year follow up examination.

* = Pathological values ( $+1-2 \cdot 5$ SD from control values); nd = not detectable.

$\mathrm{MCV}=$ motor conduction velocity; $\mathrm{DL}=$ distal latency; $\mathrm{MAP}=$ muscular amplitude potential; $\mathrm{SCV}=$ sensory conduction velocity; SAP = sensory amplitude potential.

$-=$ Normal; $\mathbf{N}=$ pathological, neurogenic features; $+=$ mild; $+++=$ moderate.
$\left({ }^{\circ}\right)=$ Number of fibres $/ \mathrm{mm}^{2} ;(c)=$ according to Dyck et al $; 9^{\circ}=$ pathological values

and 9) and sensory-motor involvement in case 5. Electrophysiological data (table) were consistent with polyneuropathy in five (cases 2,3 , 5, 6 and 7); no abnormalities were found in cases 4 and 8 , whereas the other three cases $(1$, 9 and 10) had abnormalities restricted to single nerves. Morphological and morphometric evaluation of sural nerve biopsies showed that data obtained from cases 1 and 4 were all within the range of normality. In all four of the symptomatic cases mild signs of active axonal damage with wallerian-like degeneration of myelinated fibres were present and they were located within some but not all fascicles, with a patchy and often central fascicular distribution.

In all but one case (6) clusters of small myelinated fibres surrounded by cytoplasmic leaflets from nearby Schwann cells were found and were considered a sign of regenerative features. The histogram of the distribution of myelinated fibres had a left-ward shift in cases 2,3 and 6 , while in case 5 there was a global flattening but the normal bimodal distribution was preserved. The results of ultrastructural and single teased fibre evaluations which showed an abnormally high incidence of $E$ and $\mathrm{H}$ features (that is, myelin ovoids), ${ }^{9}$ confirmed the predominant axonal damage.
Unmyelinated fibre densities and mean fibre diameters were, in all cases, at the lower limit of our normal range or just below. The histograms of their diameter distribution had the normal unimodal aspect in all cases and no morphological abnormalities were found. A statistical evaluation of the percentage of various endoneurial components revealed a marked increase in the connective tissue in three cases (2,3 and 6 ), with a decrease in fibre components, particularly myelinated ones. Both axon and myelin percentages were considerably reduced, but their relative ratio was preserved, again confirming that the entire fibre was affected by the pathological process. No deposits or infiltrates were seen within the endoneurium or perineurium. In all the four symptomatic cases endoneurial vessels showed a marked thickening of their wall due to both basal membrane reduplication and endothelial cell thickening, with abnormal infolding of the multilayered basal membrane. In most cases the lumen was nearly completely occluded by the endothelial cells. These alterations were not observed in the age related controls. No IgM or IgG deposits were detected with immunoperoxidase staining either within the endoneurium, the perineurium or the epineurium. 
At the time of the second neurological examination (table), one year later, there was a substantial stability of the haematological indices, with a mild tendency toward an improvement of the Karnofsky score in two cases and no worsening. In two cases $(5,6)$ the haematological remission was obtained with further cyclophosphamide and/or steroid treatment, while in the remaining patients no therapy adjustament was needed. Two patients $(8,9)$ were lost to follow up for non medical reasons. Only one patient (1), had poorer NSS and NDS and the neurophysiological evaluations confirmed these results.

\section{Discussion}

Cryoglobulinaemias are a group of extremely heterogeneous conditions and most of the previously reported series dealing with peripheral nervous system involvement during these haematological disorders consider a mixture of different or uncharacterised forms. ${ }^{210-12}$ It has been suggested that single component, monoclonal cryoglobulins are more likely to be associated with demyelinating features, while vasa nervorum vasculitis and the subsequent axonopathy may be more commonly associated with mixed forms. ${ }^{41314}$ Nemni et al ${ }^{11}$ recently reported IgM and IgG immunostaining in small endoneurial vessels with the PAP method in two cases, one of which was an essential mixed cryoglobulinaemia type III and one an uncharacterised form. There was, however, no immunostaining in two cases of ECII, in agreement with our findings obtained with the indirect immunoperoxidase method.

Vital et al evidenced only faint IgG immunostaining, associated with lymphocytic infiltrate, limited to epineurial vessels during the acute phase of ECII in one case. ${ }^{15}$ Only recently Garcia-Bragado et al ${ }^{16}$ described a relatively large number of patients exclusively affected by ECII evaluated clinically and electrophysiologically, with morphological confirmation of the results.

The 10 patients described in our report were all affected by ECII and eight of them had clinical symptoms and/or signs of peripheral nerve involvement at baseline. Sensory or sensory-motor polyneuropathy was suspected in six patients on clinical grounds. An asymmetric onset (that is, mononeuritis multiplex), found with ischaemic neuropathies, could not be excluded in these cases, but at the time of the neurological examinations the involvement was symmetrical in all patients. ${ }^{11} 131516$ Electrophysiological evidence of some peripheral nervous system involvement was shown in all these patients, but only five of them had definite electrophysiological evidence of polyneuropathy.

According to the criteria proposed by Kimura $^{17}$ and Kelly ${ }^{18}$ the abnormal electrophysiological data suggested largely predominant axonal damage. In fact, in our patients abnormal data were mainly represented by a moderate slowing of nerve conduction velocities, by a decrease in nerve amplitude potentials, and by the presence of fibrillation potentials and neurogenic motor unit changes in limb muscles.

In polyneuropathy associated with gammopathy the main lesion in the nerves is demyelination and this is often the case in cryoglobulinaemia as well. ${ }^{19}$ In our cases of ECII axonopathy was definitely the predominant pathological aspect, as confirmed by teased fibres and ultrastructural evaluation of sural nerve biopsies which disclosed active axonal degeneration. Additional support to this morphological observation was given by statistical evaluation of endoneurial components, which clearly demonstrated that both myelin and axon percentages were decreased in affected patients, with preservation of their relative ratio, a feature indicative of complete fibre loss. Morphometric analysis of pathological sural nerves disclosed, in three out of four cases, a predominant involvement of larger myelinated fibres. Moderate signs of regeneration were found in three cases $(2,3,5)$, in which an increased number of clusters of small myelinated fibres was present. We did not find exogenous deposits in endothelial cells, endoneurial vessels or endoneurium, in contrast with the unique ultrastructural report by Vallat. ${ }^{20}$ This report referred to a case of monoclonal cryoglobulinaemia associated with myeloma in which demyelinating features were present.

In our pathological cases endoneurial vessels often appeared affected by non-specific changes, similar to those found in some cases of diabetic $^{21}$ and of IgM monoclonal gammopathy ${ }^{19}$ neuropathies. No acute signs of vasculitis were found either in the endoneurium or in the perineurium or epineurium. Evidence of active vasculitis was found in this series at the onset of the disease in cutaneous biopsies in all patients $(9 / 10)$ in which purpura was the presenting sign. However, all cases but one (5) had immunosuppressive therapy before nerve biopsy, generally with satisfactory response. The absence of active inflammatory reaction at the time of nerve biopsy may therefore be due to the effectiveness of treatment. It may be postulated that the vigorous immunosuppressive therapy administered to most of our patients before sural nerve biopsy could have played a role in the pathogenesis of peripheral nerve damage in this series. It is remarkable that both patients in which sural nerve findings were normal $(1,4)$ were treated with immunosuppressive drugs, and one of them (1) assumed the largest total dose in the series. Moreover, no relationship between total dose of drugs and severity of neuropathy was found.

The evaluation of this series of patients affected by peripheral neuropathy during ECII demonstrates that axonal damage is the main pathological feature of this condition. We believe that the axonal damage, the patchy distribution of the lesions, the marked thickening of the vessel wall, associated with the negative immunoperoxidase staining for IgG and IgM in sural nerve biopsies, all suggest the involvement of ischaemia as a cause of the neuropathy. All the patients had been carefully followed to obtain haematological remission and all the eight patients who had the follow up 
neurological examination had no significant worsening of their haematological condition. We believe that a correlation seemed to occur between haematological and neurological outcome after one year.

We are very grateful to Dr $M$ Castoldi for his surgical assistence and to Ms G Fiori and Mr L Losi for their expert technical assistance.

This work was presented in part at the First Meeting of the

European Neurological Society, Nice, 19-22 June 1988 .

The study was supported by a grant from The Italian National Research Council.

1 Brouet JC, Clauvel JP, Danon F, Klein M, Seligmann AM. Biologic and clinical significance of cryoglobulins. A report of 86 cases. Am J Med 1974;57:775-88.

2 Logothesis J, Kennedy WR, Ellington A, Williams RC. Cryoglobulinemic neuropathy. Arch Neurol 1968;19: 389-97.

3 Valli G, Barbieri S, Gaddi L, De Vechhi A. Caratteristiche ed incidenza della neuropatia in corso di crioglobulinemia essenziale. Proc 25th Congress Ital Neurol Soc, Bologna 1987:54.

4 Chad D, Pariser K, Bradley WG, Adelman LS, Pinn VW. The pathogenesis of cryoglobulinemic neuropathy. $82 \cdot 32 \cdot 725-9$.

5 McLeod JC, Walsh JC, Pollard JD. Neuropathies associated with paraproteinemias and dysproteineamias. In: Dyck PJ, Thomas PK, Lambert EH, Bunge R, eds. Peripheral neuropathy 2nd ed. London and Philadelphia: WB Saunders, 1984:1847-65.

6 Dyck PJ, Sherman WR, Hallcher LM, et al. Human diabetic endoneural sorbitol, fructose and myo-inositol related to sural nerve morphometry. Ann Neurol 1980;8:590-6.

7 WHO handbook for reporting results of cancer treatment. Geneva: WHO, 1979: publication 48.
8 Karnofsky DA, Burchenal JH. The clinical evaluation of chemotherapeutic agents in cancer. In: McLeod CM, ed. Evaluation of chemotherapeutic agents. New York: ed. Evaluation of chemotherapeutic agents.

9 Dyck PJ, Karnes J, Lais A, Lofgren EP, Stevens JC. Pathologic alterations of the peripheral nervous system of humans. In: Dyck PJ, Thomas PK, Lambert EH, Bunge $\mathrm{R}$, eds. Peripheral neuropathy 2nd ed. London and Philadelphia: WB Saunders, 1984:760-870.

10 Dayan AD, Lewis PD. Demyelinating neuropathy in macrocryoglobulinemia. Neurol 1966;16:1141-4.

11 Nemni R, Corbo M, Fazio R, Quattrini A, Comi G, Canal N. Cryoglobulinemic neuropathy. A clinical, morphological and immunocytochemical study of 8 cases. Brain 1988; 111:541-52.

12 Pavesi G, Geminiani F, Manganelli P, Mancia D, Marbini A. Polyneuropathy and systemic vasculitis. An electrophysiological study. Ital J Neurol Sci 1987;8:171-6.

13 Abramsky O, Slavin S. Neurologic manifestations in patients with mixed cryoglobulinemia. Neurol 1974;24: patients

14 Lippa CF, Chad DA, Smith TW, Kaplan MH, Hammer K. Neuropathy associated with cryoglobulinemia. Muscle Nerve 1986;9:626-31.

15 Vital C, Deminiere C, Lagueny A, et al. Peripheral neuropathy with essential mixed cryoglobulinemia: biopsies from 5 cases. Acta Neuropathol (Berl) 1988;75:605-10.

16 Garcia-Bragado F, Fernandez JM, Navarro C, Villar M, Bonaventura I. Peripheral neuropathy in essential mixed cryoglobulinemia. Arch Neurol 1988;45:1210-4.

17 Kimura J. Electrodiagnosis in diseases of nerve and muscle. Principles and practice. Philadelphia: FA Davis, 1983: 74-6.

18 Kelly JJ. The electrodiagnostic findings in peripheral neuropathy associated with monoclonal gammopathy. Muscle Nerve 1983;6:504-9.

19 Meier C. Polyneuropathy in paraproteinemia. J Neurol 1985;232:204-14.

20 Vallat JM, Desproges-Gotteron R, Leboutet MJ, Loubet $A$, Gualdne N, Treves R. Cryoglobulinemic neuropathy: a pathological study. Ann Neurol 1980;8:179-85.

21 Powell HC, Rossof J, Myers RR. Microangiopathy in human diabetic neuropathy. J Neuropathol Exp Neurol 1985; 